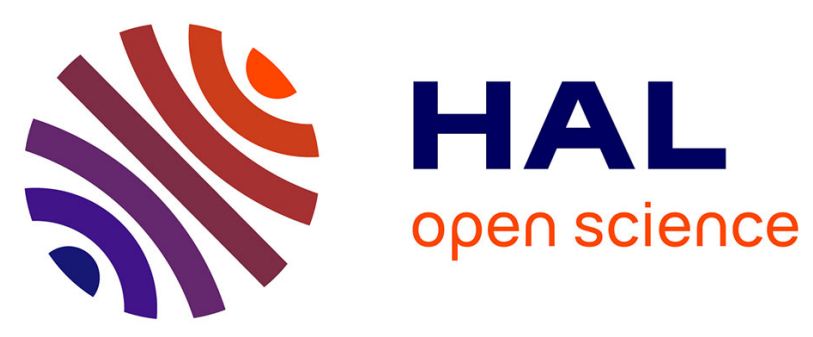

\title{
Morphological controls on the dynamics of carbonate landscapes under a mediterranean climate
}

Franck Thomas, Vincent Godard, Olivier Bellier, Esmaeil Shabanian, Vincent

Ollivier, Lucilla Benedetti, Magali Rizza, Nicolas Espurt, Valery Guillou, Fabrice Hollender, et al.

\section{To cite this version:}

Franck Thomas, Vincent Godard, Olivier Bellier, Esmaeil Shabanian, Vincent Ollivier, et al.. Morphological controls on the dynamics of carbonate landscapes under a mediterranean climate. Terra Nova, 2017, 29 (3), pp.173-182. 10.1111/ter.12260 . hal-01784741

\section{HAL Id: hal-01784741 \\ https://hal-amu.archives-ouvertes.fr/hal-01784741}

Submitted on 3 May 2018

HAL is a multi-disciplinary open access archive for the deposit and dissemination of scientific research documents, whether they are published or not. The documents may come from teaching and research institutions in France or abroad, or from public or private research centers.
L'archive ouverte pluridisciplinaire HAL, est destinée au dépôt et à la diffusion de documents scientifiques de niveau recherche, publiés ou non, émanant des établissements d'enseignement et de recherche français ou étrangers, des laboratoires publics ou privés. 


\section{Morphological controls on the dynamics of carbonate landscapes}

\section{under mediterranean climate}

Franck Thomas ${ }^{1}$, Vincent Godard ${ }^{1}$, Olivier Bellier ${ }^{1}$, Esmaeil Shabanian ${ }^{1,}{ }^{\dagger}$, Vincent Ollivier ${ }^{2}$, Lucilla Benedetti $^{1}$, Magali Rizza ${ }^{1}$, Nicolas Espurt, Valéry Guillou ${ }^{1}$, Fabrice Hollender ${ }^{3,4}$, Stéphane Molliex $^{5}$, ASTER Team ${ }^{1}$

${ }^{1}$ Aix-Marseille Université, CNRS, IRD, CDF, CEREGE UM34, 13545 Aix-en-Provence, France

${ }^{2}$ Aix Marseille Université, CNRS, Minist Culture \& Com, LAMPEA, Aix-en-Provence, France

${ }^{3}$ CEA, DEN, F-13108 Saint Paul lez Durance, France

${ }^{4}$ Université Grenoble Alpes/CNRS/IRD/IFSTTAR, ISTerre, F-38000 Grenoble, France

${ }^{5}$ Laboratoire Géosciences Océan, UMR CNRS 6538, Institut Universitaire Européen de la Mer, Université de Bretagne Occidentale, place N. Copernic, F-29280 Plouzané, France

${ }^{*}$ Corresponding author : thomas@cerege.fr

$\uparrow$ Now at: Institute for Advanced Studies in Basic Sciences, Gava Zang - Zanjan, Iran elle

How to cite this article : Thomas, F., Godard, V., Bellier, O., Shabanian, E., Ollivier, V., Benedetti, L., Espurt, N., Guillou, V., Hollender, F., Molliex, S., ASTER Team (2017). Morphological controls on the dynamics of carbonate landscapes under a mediterranean climate, Terra Nova, 00:1-10. https://doi.org/10.1111/ter.12260 


\begin{abstract}
The influence of the morphological setting on the denudation of carbonate landscapes and the respective contributions of mechanical and chemical weathering processes are still debated. We have addressed these questions by measuring ${ }^{36} \mathrm{Cl}$ concentrations in 40 samples from the Luberon mountain, SE France, in order to constrain denudation of various landscape elements. We observe a clear contrast between the local denudation rates from the flat summit surface clustered around 30 $\mathrm{mm} / \mathrm{ka}$ and the basin average denudation rates across the flanks ranging from 100 to $200 \mathrm{~mm} / \mathrm{ka}$. This difference highlights the transient evolution of the range whose topography is still adjusting to previous uplift events. Such a pattern also suggests that carbonate dissolution is not the only driver of denudation in this setting, which appears to be significantly controlled by slope-dependent processes.
\end{abstract}

\title{
Introduction
}

Topographic relief evolution over Quaternary timescales is reflecting the combined influences of climatic and tectonic variabilities (e.g. Champagnac et al., 2014) but, in most situations it is difficult to deconvolve the respective contributions of the various forcings. Understanding the dynamics of the Earth's surface requires the assessment of the rates of evolution of the different landscape features, such as plateau surfaces, hillslopes or ridges. Such quantification allows to detect the existence of transient conditions associated with relief growth or decay which can be related to variations in the tectonic or climatic boundary conditions.

The measurements of in-situ cosmogenic nuclides concentrations, notably ${ }^{10} \mathrm{Be}$ in quartz-rich substrates, have provided valuable insights on the rates and modes of continental relief evolution over the 1-100 ka time window, and in particular on the steady or transient state of topography. For example, Meyer et al. (2010) have compared spatially-averaged denudation rates of river catchments with local estimates on ridges in the Black Forest, Germany. They show a crest lowering rate significantly lower than denudation at the landscape scale, which can be considered as 
a manifestation of relief growth. Along the Western Ghats of Peninsular India, Mandal et al. (2014) observed a similar discrepancy between interfluves and catchment-averaged denudation, which they interpret as the manifestation of local disequilibrium in relief evolution at short-wavelength.

Most of these studies have focused on areas dominated by quartz rich bedrock, due to the routine use of in-situ ${ }^{10} \mathrm{Be}$ to determine denudation rates. In contrast, only a few studies have used ${ }^{36} \mathrm{Cl}$ to investigate the denudation in carbonate-dominated landscapes (Stone et al., 1994; Matsushi et al., 2010 ; Xu et al., 2013). Recent work by Ryb et al (2014a,b, 2015) in Israel have pushed forward the use of ${ }^{36} \mathrm{Cl}$ to derive an integrated understanding of the dynamics of Mediterranean landscapes. For example, they highlight the importance of climatic gradients in controlling the dominant modes of surface weathering. In a carbonate range of Provence, southeastern France, Godard et al. (2016) have used similar approaches to derive a model of hillslope evolution, showing the existence of an important threshold for weathering processes promoting relief growth in a carbonate mountain range.

These studies, however, have either focused on the very local scale of individual hillslopes or on the regional scale of a climatic gradient, and there is currently a significant knowledge gap at the intermediate scale of a single range. More specifically, the importance of slope-independent processes such as carbonate congruent dissolution complicates the a-priori appraisal of the relationships between morphology and denudation rates. For instance, in ranges characterized by varying hillslope gradients, it is difficult to assess whether such spatial variations are controlling the denudation pattern or if dissolution is going to impose spatially homogeneous surface lowering.

Here we used cosmogenic ${ }^{36} \mathrm{Cl}$ measurements to quantify the rates of evolution of different landscape elements in a carbonate range of South-Eastern France. We focused on the Petit Luberon, where 40 carbonate rock samples were collected, both on the flat summit surface, to estimate local lowering, and at the outlets of catchments draining both flanks to compute basin-average denudation rates. Our main objective was to test if denudation, in this carbonate landscape, is homogeneous at the scale of the range or, at least in part, controlled by topographic gradients. 


\section{Geological and geomorphological setting}

The landscape of Provence in SE France is dominated by East-West trending carbonate ranges (figure 1) associated with major structures that were reactivated as normal faults during the Oligocene (Roure et al., 1992) and as reverse or strike-slip faults during the Alpine Miocene compressive phase (Champion et al., 2000; Baroux et al., 2001; Chardon and Bellier, 2003; Molliex et al., 2011). The latter deformation phase resulted in the uplift and rejuvenation of pre-existing landscapes (Bestani et al., 2016). Various studies (Chardon et al., 2005; Chardon and Bellier, 2003; Nocquet, 2012) indicate that the post-Miocene rate of deformation in Provence is very slow.

In the Luberon range, Clauzon et al. (2011) recognized the imprint of two Miocene tectonic phases. In the early Miocene, a first phase induced additional shortening across the Eocene anticline of the Petit Luberon (Langhien, $\sim 14 \mathrm{Ma}$ ), while a second Tortonian phase ( $\sim 12 \mathrm{Ma}$ ) mainly affected the Grand Luberon. After the Miocene, deformation was mostly transferred to the south. The investigation of pollen sequences in the foreland of the Luberon range confirms the occurrence of a major uplift event between the Serravalian (12-13Ma) and the Tortonian, followed by $\sim 600 \mathrm{~m}$ of surface lowering of the crest (Fauquette et al., 2015). The current Luberon mountain consists of two main ranges: the Grand Luberon and Petit Luberon, from east to west, with maximum elevations of 1125 and $726 \mathrm{~m}$ asl. respectively (figure 1). The Petit Luberon summit surface is flat and locally reaches a width of 500 meters. It is underlain by lower Cretaceous bioclastic carbonates, which are also present across the northern flank, whereas the southern flank is dominated by an Hauterivian series with alternating marl and limestone beds.

The progressive incision of small valleys and gullies into the relatively flat summit surfaces (figure 2A and $2 \mathrm{~B}$ ) suggests a transient evolution, which is confirmed by local hillslopes dynamics (Godard et al., 2016), but needs to be tested with denudation data at the scale of the range. The location, extent and homogeneous mean annual precipitations (MAP) of $\sim 700 \mathrm{~mm}$ of the Petit Luberon insure that there is no strong climatic, tectonic or lithological variability over the studied area, 
which is an ideal setting for the investigation of the relationships between denudation and geomorphic parameters.

\section{Methods and results}

We used ${ }^{36} \mathrm{Cl}$ concentrations to quantify denudation at 24 sites on the Petit Luberon. ${ }^{36} \mathrm{Cl}$ accumulates in near surface carbonates mostly because of the interactions of $\mathrm{Ca}$ with secondary cosmic rays, and has been used to document exposure or denudation history of limestone bedrock (e.g. Stone et al. 1994; Ryb et al. 2014a,b; Godard et al., 2016). Samples preparation and chlorine extraction was done using the protocol described in Schlagenhauf et al. (2010) and measurements of the chlorine isotopic ratios were performed at the French AMS National Facility, ASTER, located in CEREGE. Denudation rates have been calculated from ${ }^{36} \mathrm{Cl}$ concentrations under a steady state assumption (Ryb, 2014a\&b) using the approach described by Schimmelpfennig et al. (2009). See table 1 for further details on the analytical results and parameters used for the derivation of denudation rates.

We collected two types of carbonate samples: 16 bedrock or amalgamated clasts from the flat summit surface, and 24 stream sediments from small catchments, draining the northern and southern flanks of the range. The main goal was to document the distribution of denudation across the range and to assess the magnitude of the differences in denudation rates between the preserved surface and the dissected flanks. On the crest, when possible, both bedrock and amalgamated clasts were sampled at a same site in order to evaluate the effect of regolith dynamics on erosion rates. For stream sediment samples, when possible, both sand and gravels have been sampled at a single location in order to test the influence of sediment size on the basin-averaged denudation rates (Carretier et al., 2015). In addition, basin parameters such as mean altitude, mean slope and relief were calculated in order to estimate their respective influence on denudation. Normalized steepness indexes $\left(\mathrm{k}_{\mathrm{sn}}\right)$ were calculated for each basin (Kirby and Whipple, 2012) using a slope-area regression and a reference concavity of 0.45 .

Measured denudation rates range from 26.5 to $205.3 \mathrm{~mm} / \mathrm{ka}$ (see table 1). The lowest rates are 
observed in the bedrock and amalgamated clasts from the large, flat summit surface, which cluster around $30 \mathrm{~mm} / \mathrm{ka}$. One surface sample (MAY01C-A) consisting of carbonate clasts presents a denudation rate of $68 \mathrm{~mm} / \mathrm{ka}$ but was collected on a secondary surface at a lower elevation. Denudation is one order of magnitude faster on the flanks than on the summit as stream sediment samples yield rates in the $100-200 \mathrm{~mm} / \mathrm{ka}$ range (figure 3). The distribution of denudation between the two sides of the range is variable. Denudation rates cluster around 100-120 and 150-180 mm/ka across the northern flank, whereas they are distributed between 100 and $190 \mathrm{~mm} / \mathrm{ka}$ in the southern flank.

\section{Discussion}

Measured ${ }^{36} \mathrm{Cl}$ concentrations of bedrock and clast samples from the crest present similar values (figure 4), which suggests that these clasts are not the remnants of a thicker eroded regolith layer (Godard et al., 2016). For some watershed outlets on the Petit Luberon flanks, both sand and gravels have been analyzed and no clear systematic influence of grain size on the measured denudation rates was observed (figure 5).

Denudation rates from the summit surface are consistent with other millennial denudation rates from cosmogenic nuclides or annual direct erosion measurements in carbonate landscapes (figure 3). Ryb et al. (2014a) obtained slightly lower values in the Mediterranean to semi-arid regions of Israel, where precipitation is significantly lower than in our study area. Matsushi et al. (2010) obtained rates in the 20-60 $\mathrm{mm} / \mathrm{ka}$ range in a karstic domain in Japan where mean annual precipitation (MAP) is 1000 to $2000 \mathrm{~mm}$. Xu et al. (2013) found similar denudation rates in the Guizhou karst, China (MAP 900-1300 mm). Both previous studies obtained denudation rates with similar ranges as our dataset in the Luberon where MAP is $700 \mathrm{~mm}$, which highlights the importance of water availability and chemical dissolution in controlling carbonate weathering, as proposed by Ryb et al. (2014a).

Average basin denudation rates display comparable ranges between the northern $(100-120 \mathrm{~mm} / \mathrm{ka}$ 
and $150-180 \mathrm{~mm} / \mathrm{ka})$ and southern flank $(100-190 \mathrm{~mm} / \mathrm{ka})$. Despite the fact that the topography is asymmetric and the northern flank is significantly shorter than the southern one, the average slope values for the studied catchments located on both flanks are also similar (from $18^{\circ}$ to $26^{\circ}$ ). The bedrock geology of the flanks is very contrasted. On the northern flank, the strata dip between $20^{\circ}$ and $40^{\circ}$ to the North (BRGM 1/50000 geological map), whereas on the southern flank, the distribution of dip angles is more variable, with a dip towards the north $\left(15-25^{\circ}\right)$ just south of the main crest of the range and a dip to the south on the southernmost part, forming an anticlinal fold whose axis is located South of the summit (figure 6). Additionally, a clear lithologic contrast exists between the two flanks, with a more erodible marl and limestone series (Hauterivian) on the southern flank and a massive carbonate sequence (Urgonian) in the North. These contrasts in bedrock geology are not reflected in terms of differential denudation between the two flanks, and probably play a minor role in the recent geomorphological evolution of the range.

We compared basin-wide denudation rates with the main basin morphological parameters (figure 5). The flanks are separated in order to show the possible influence of differences in the geological and morphological setting between the two sides of the range. No obvious trend between denudation rates and the various tested parameters can be inferred on the southern flank of the range. In particular, mean basin slope and mean altitude have apparently no influence on basin denudation. In contrast, denudation rates of the northern flank display a clearer positive relationship with slope, relief, and normalized steepness index. We suggest that the difference of behavior between the flanks could be a result of the contrast in morphology and geology (figure 6). The complex structure and spatial variability in the southern flank might blur the relationships between morphology and denudation, whereas the more homogeneous northern flank allows the expression of a clearer morphological control.

We interpret the very strong contrast in denudation between the summit surface and the flanks as a consequence of a transient state of the range (figure 6A). This evolution corresponds to the progressive narrowing and dismantling of the summit surface by regressive erosion from the flanks. 
Such high denudation on the flanks and the fact that the range is not homogeneously lowering highlights the importance of slope-dependent processes in the evolution of these carbonate landscapes. Progressive dissolution might be the dominant denudation process across the flat summit surface, but physical weathering is likely to contribute significantly to the evolution of the steep flanks of the range, at least in the range of climatic conditions we are investigating here (Ryb et al., 2014a).

This topographic disequilibrium could be inherited from an earlier uplift and relief rejuvenation event. While climatic fluctuations over the Late Cenozoic have certainly modulated weathering processes in these carbonate landscapes, the extrapolation of our results from the summit surface over the last $10 \mathrm{Ma}$ would imply a total denudation of several hundred meters. Interestingly, Fauquette et al. (2015) report the occurrence of high elevation pollens in Serravalian sediments from the foreland of the Grand Luberon, suggesting comparable decrease in elevation in that part of the range since the last recorded major tectonic event.

Beyond the specific case of the Luberon mountain range, our findings have important implications for the geomorphological evolution of carbonate landscapes under Mediterranean climate. The endmember case of large karstic carbonate plateaus, devoid of the common ridges and valleys signature of many landscapes (Perron et al., 2009), highlights the importance of congruent dissolution as a geomorphic agent over long-wavelengths. On the other hand, in ranges such as the Luberon, it appears that denudation processes are also sensitive to topographic gradients and lead to the development of distinct ridges and valleys dissecting the flank of the range. Ryb et al. (2014a\&b) also report various degrees of carbonate landscape sensitivity to slope-dependent processes. The reason for the shift between one type of behavior to another might depend on a combination of parameters. Under the type of Mediterranean climate we investigate, where water availability is not a limiting factor, bedrock properties could control the amount of overland flow and the emergence of a hillslope-channel transition. 


\section{Conclusions}

We collected a dense dataset documenting carbonate denudation across a single range, consistent with similar studies on denudation in carbonate domains. Our study is one of the first to observe a strong denudation gradient clearly correlated with morphology in this kind of environments. It suggests that, in this Mediterranean setting, carbonate landscapes are not undergoing homogeneous lowering driven by chemical weathering but rather that their denudation is significantly controlled by topographic gradients.

\section{Acknowledgments}

This study was supported by the ECCOREV research federation, INSU-CNRS and the Cashima Research Project (funded by the CEA Cadarache and ITER Organisation). Franck Thomas benefited from a PhD scholarship funded by the CEA and the Conseil Regional PACA. We thank the Parc Naturel Régional du Luberon and the Office National des Forêts for facilitating access to our field sites. The ${ }^{36} \mathrm{Cl}$ measurements were performed at the ASTER AMS national facility (CEREGE, Aix en Provence) which is supported by the INSU/CNRS, the ANR through the "Projets thématiques d'excellence" program for the "Equipements d'excellence" ASTER-CEREGE action, IRD and CEA. This work is also a contribution to the Labex OT-Med (n ANR-11-LABX-0061) funded by the French Government «Investissements d'Avenir» program of the French National Research Agency (ANR) through the A*MIDEX project (n ANR-11-IDEX-0001-02). 

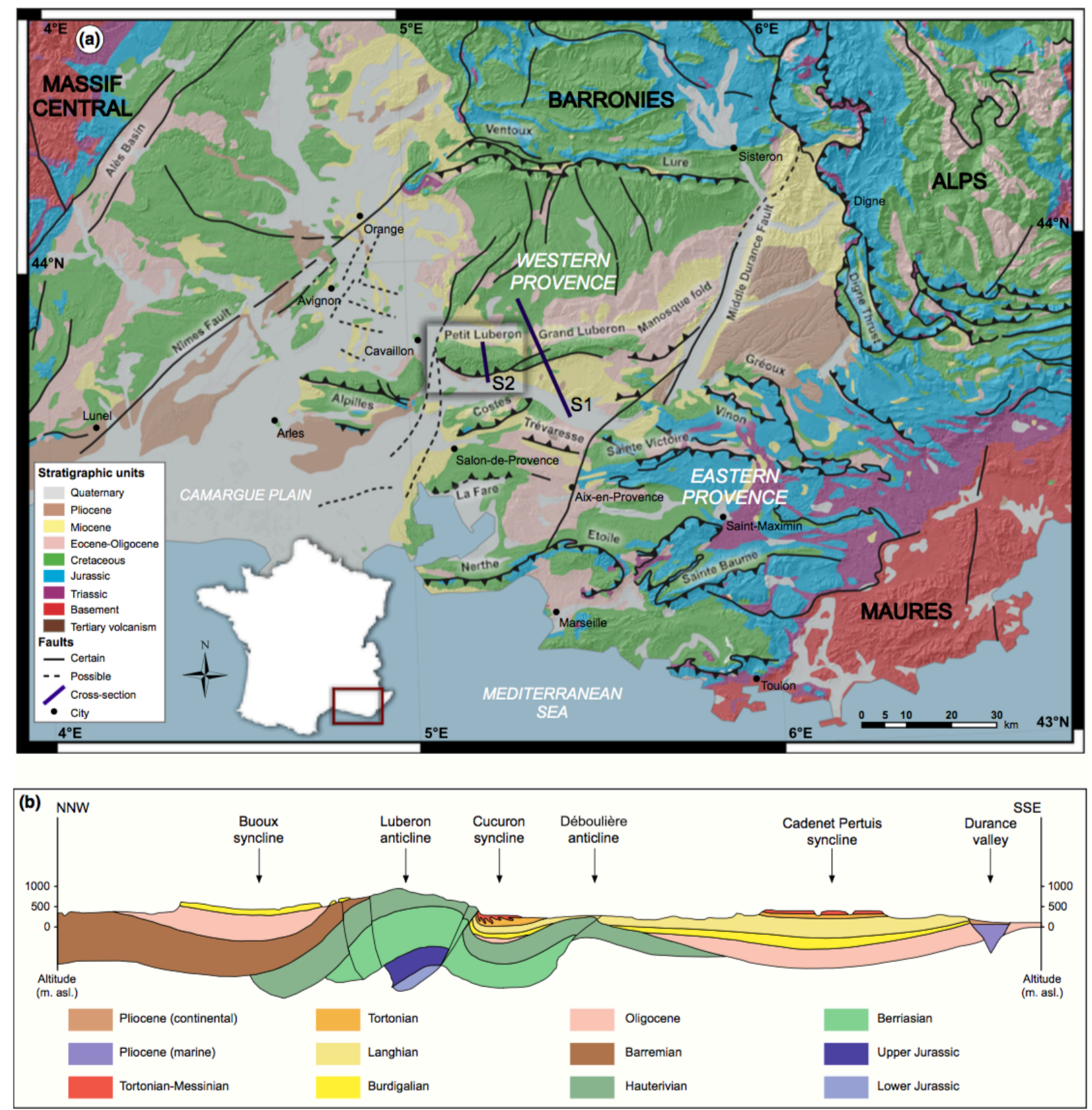

Figure 1 - A: Geological map of South-Eastern France (modified from Molliex et al., 2011) showing the principal faults and ranges in Provence. The square indicates the location of the Petit Luberon.B: Geological section S through the Grand Luberon mountain (modified from Clauzon et al., 2011). 

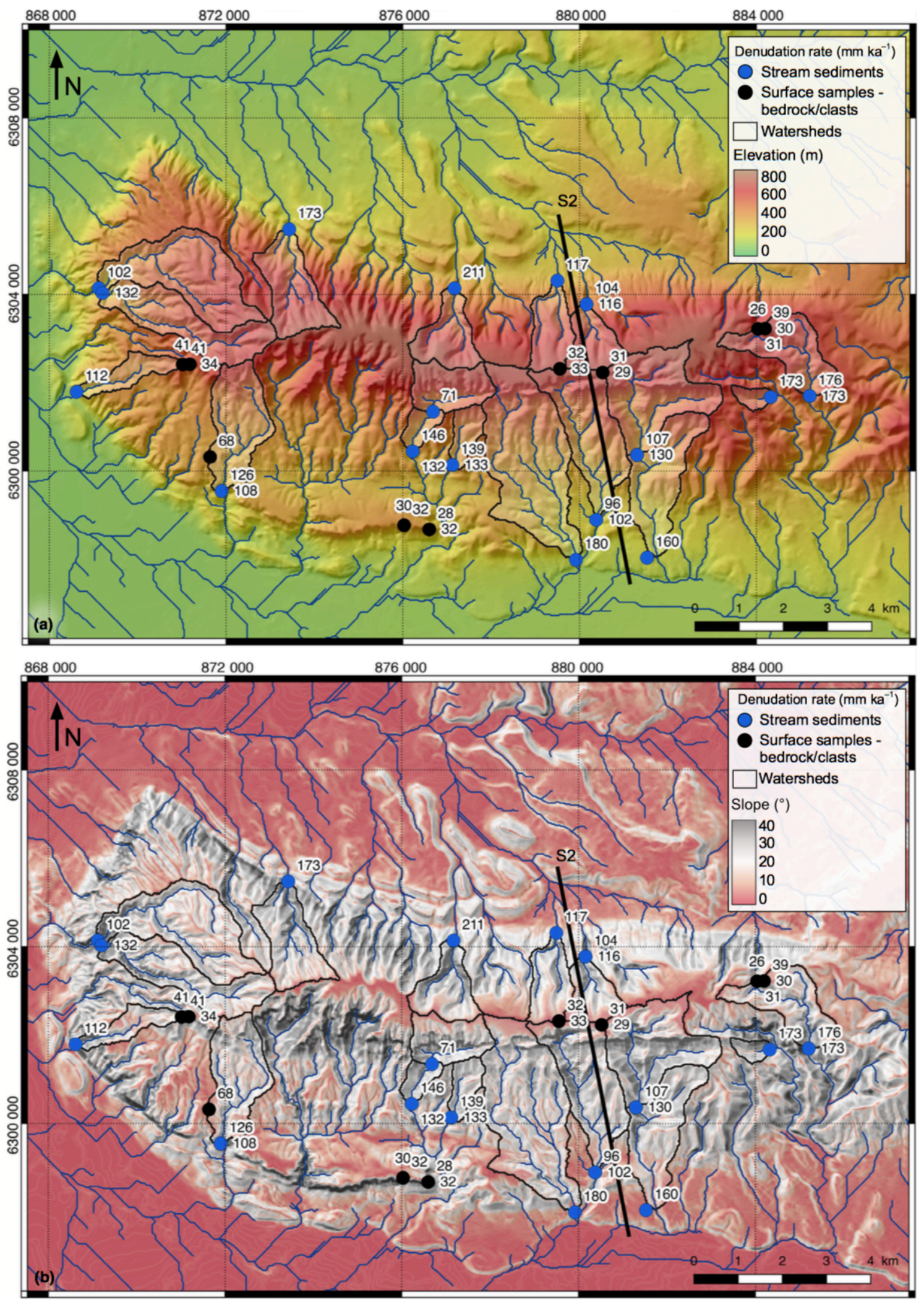

Figure 2 - A: Topographic map of the Petit Luberon with sampling locations and denudation rates (in $\mathrm{mm} / \mathrm{ka}$ ). See figure 1 for location. Light blue shading indicates the watersheds corresponding to stream sediments. Black line indicates the location of the topographic and geologic section from figure 6A. B: Slope map of the Petit Luberon highlighting the flat summit surface of the range. 

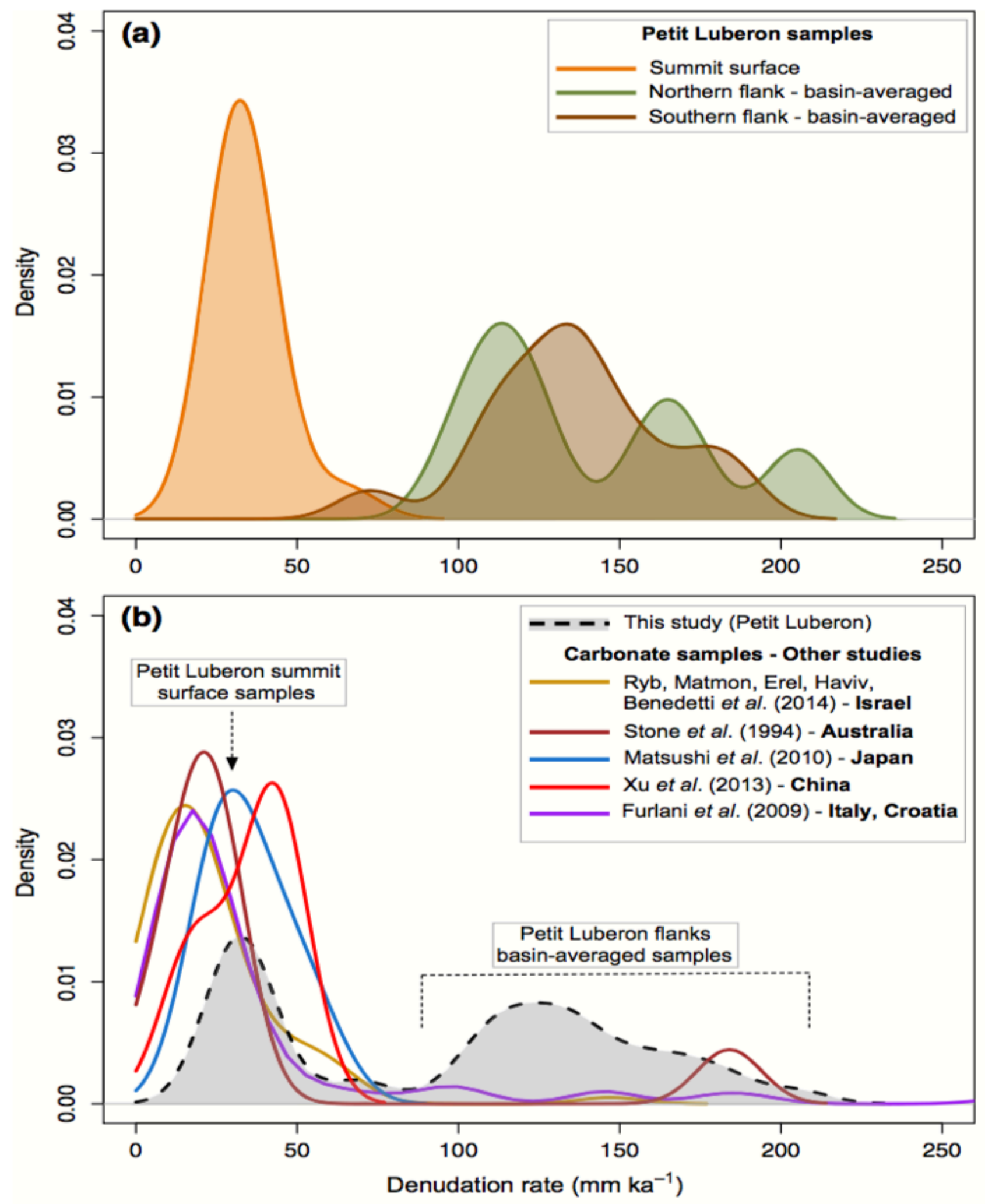

Figure 3 - A: Distribution of denudation rates on the Petit Luberon and in other carbonate landscapes (kernel density function). A: Distribution of denudation rates on the Petit Luberon depending on the sampling location (crest, northern flank and southern flank). B: Comparison of denudation rates in the Petit Luberon with results from previous similar studies in carbonate landscapes. 


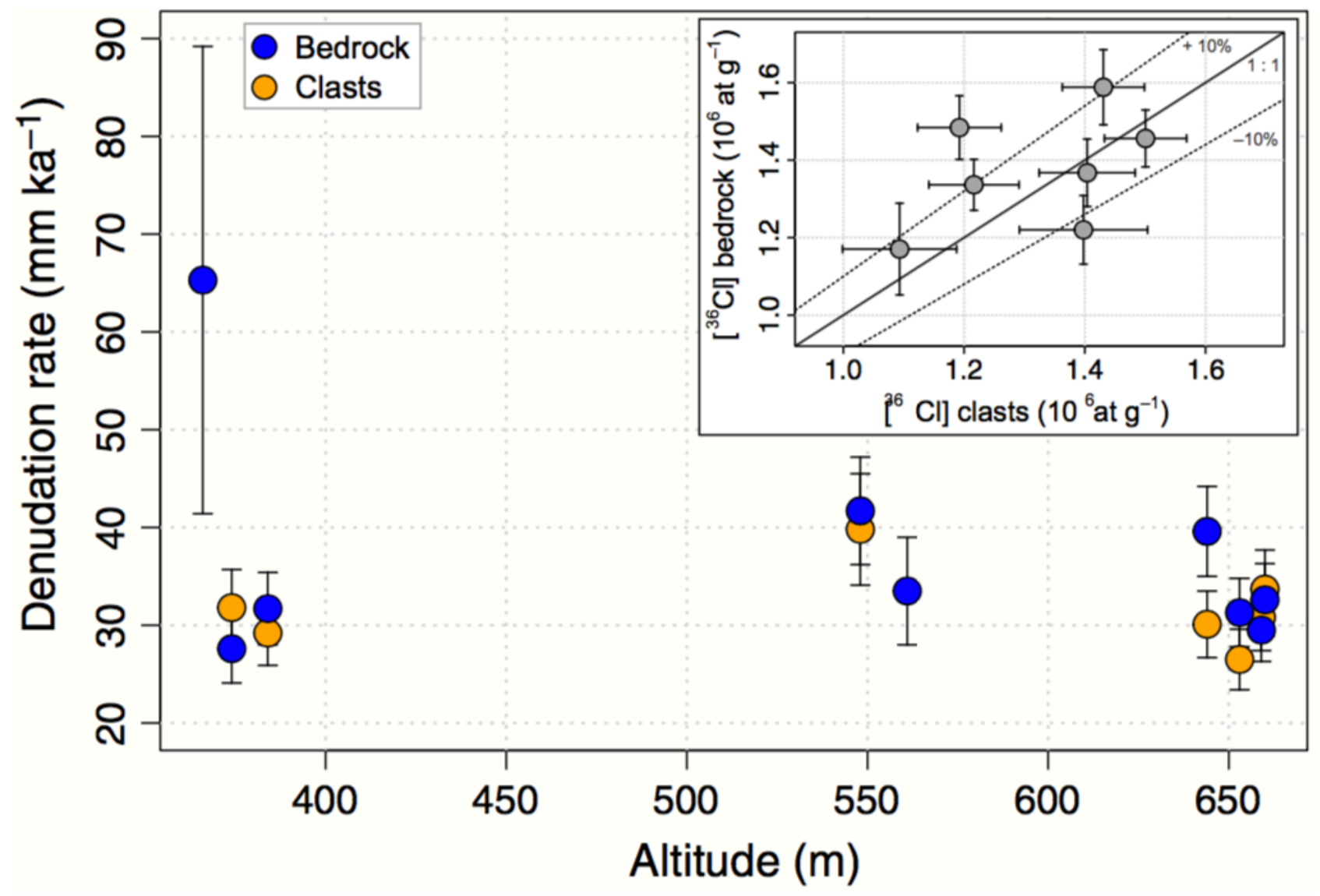

Figure 4 - Denudation rates for surface samples (bedrock or clasts) in the Petit Luberon as a function of the elevation of the sampling site. The inset shows the ${ }^{36} \mathrm{Cl}$ concentrations in clasts and bedrock samples. 

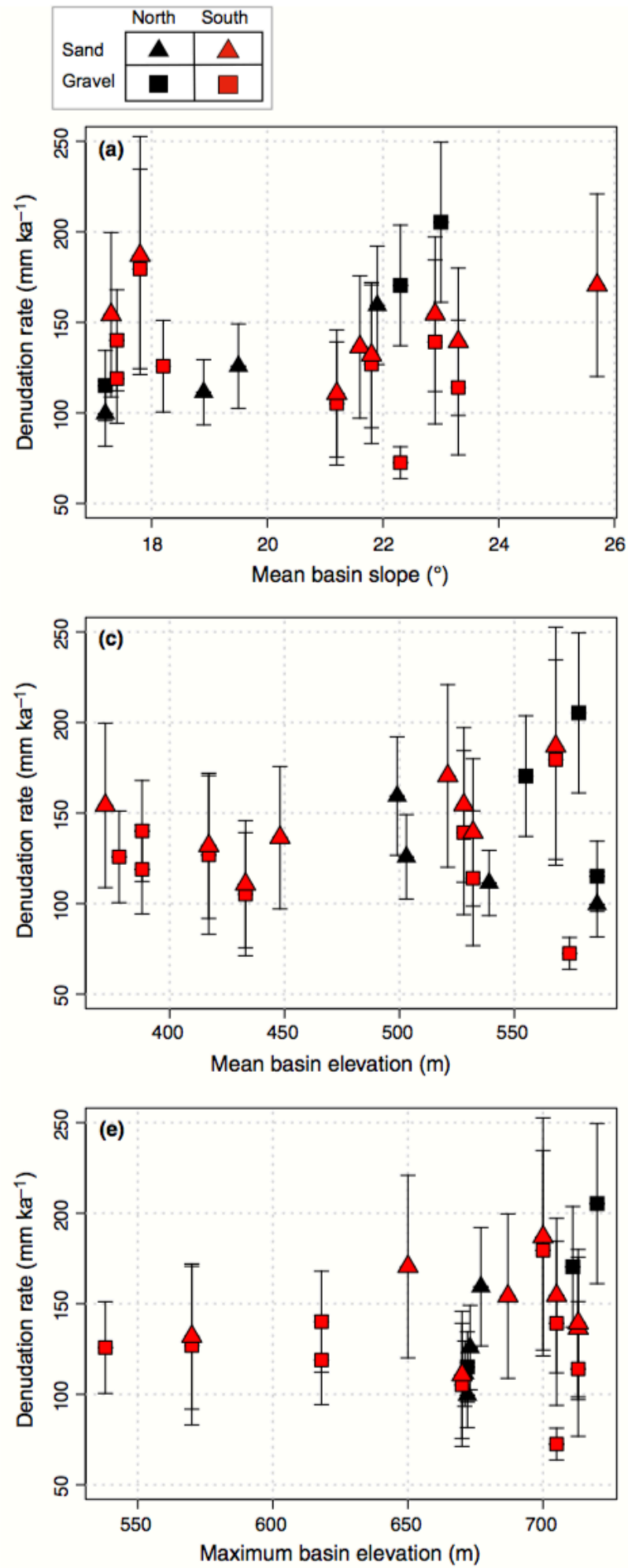
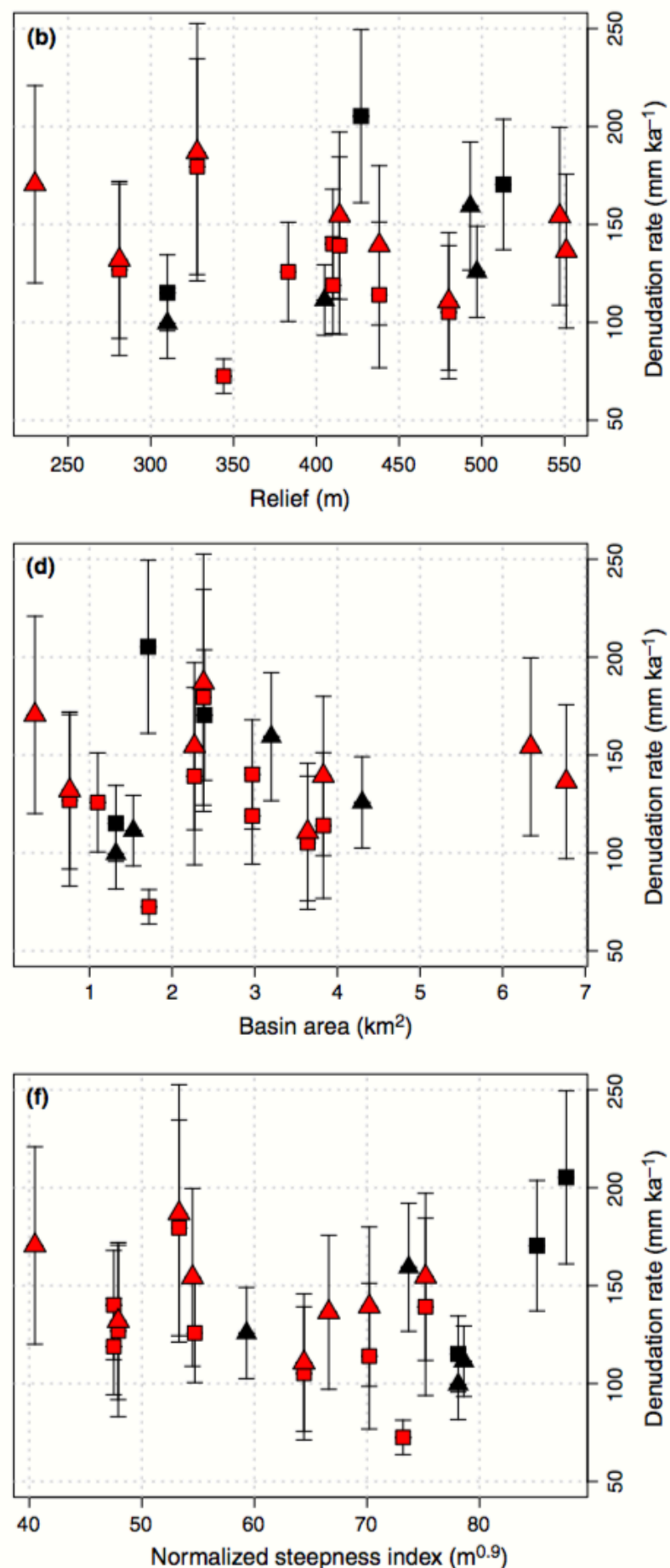

Figure 5 - Catchment-averaged denudation rates in the Petit Luberon flanks as a function of various morphological parameters. Symbol color indicates the location of the catchment (southern or northern flank) and symbol shape indicates the grain size of the sample (sand or gravel). 

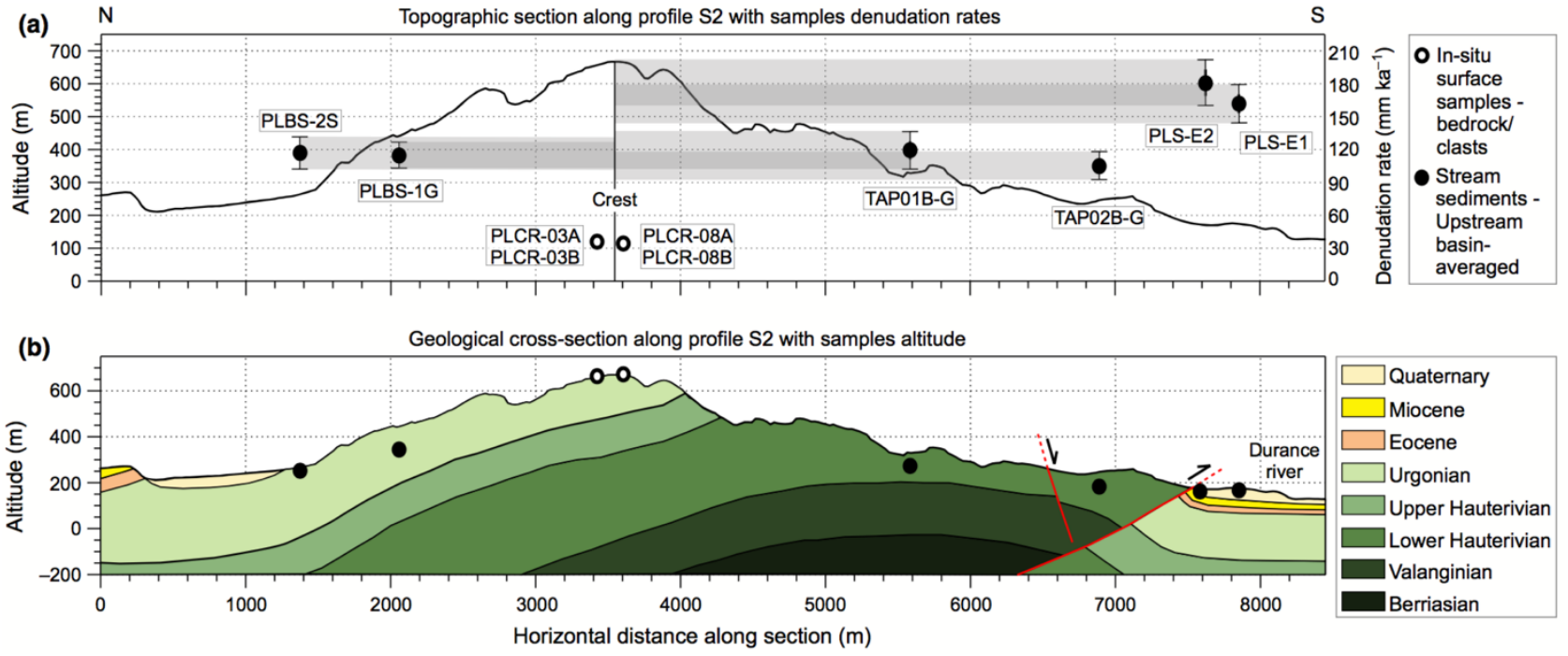

Figure 6-A: North South topographic profile (see figure 2 for location) through the central part of the Petit Luberon with measured denudation rates. B: Geological cross section across the Petit Luberon anticline. The northern flank is characterized by homogeneously northward dipping strata and a single lithology whereas the geological context of the southern flank is more complex. 


\begin{tabular}{|c|c|c|c|c|c|c|c|c|c|}
\hline Sample ID & Location & Type & Latitude & Longitude & Altitude & [Ca] & {$[\mathrm{Cl}]$} & {$\left[{ }^{36} \mathrm{Cl}\right]$} & Denudation \\
\hline & & & ${ }^{\circ} \mathbf{N}$ & ${ }^{\circ} \mathbf{E}$ & $\mathbf{m}$ & $\%$ & ppm & $10^{5}$ atom $/ \mathrm{g}$ & $\mathbf{m m} / \mathbf{k a}$ \\
\hline \multicolumn{10}{|c|}{ Surface samples } \\
\hline MAY01C-A & Secondary & Clasts & 43.7809 & 5.1318 & 366 & 40.5 & 47.07 & $8.27 \pm 2.92$ & $65.3 \pm 23.9$ \\
\hline PLCR-01A & Summit & Clasts & 43.8038 & 5.2871 & 653 & 38.2 & 1.42 & $14.31 \pm 0.68$ & $31.3 \pm 3.5$ \\
\hline PLCR-01B & Summit & Bedrock & 43.8038 & 5.2871 & 653 & 35.3 & 2.62 & $15.89 \pm 0.97$ & $26.5 \pm 3.1$ \\
\hline PLCR-02A & Summit & Clasts & 43.8035 & 5.2888 & 644 & 39 & 2.18 & $11.92 \pm 0.69$ & $39.6 \pm 4.6$ \\
\hline PLCR-02B & Summit & Bedrock & 43.8035 & 5.2888 & 644 & 38.7 & 2.18 & $14.84 \pm 0.82$ & $30.1 \pm 3.4$ \\
\hline PLCR-03A & Summit & Clasts & 43.7965 & 5.2310 & 660 & 38.5 & 2.14 & $14.04 \pm 0.79$ & $32.6 \pm 3.7$ \\
\hline PLCR-03B & Summit & Bedrock & 43.7965 & 5.2310 & 660 & 38.4 & 2.50 & $13.67 \pm 0.87$ & $33.7 \pm 4.0$ \\
\hline PLCR-08A & Summit & Clasts & 43.7960 & 5.2426 & 659 & 37.9 & 1.16 & $15.01 \pm 0.68$ & $29.5 \pm 3.2$ \\
\hline PLCR-08B & Summit & Bedrock & 43.7960 & 5.2426 & 659 & 38 & 1.69 & $14.56 \pm 0.73$ & $30.8 \pm 3.4$ \\
\hline PHA01C-A & Secondary & Clasts & 43.7663 & 5.1856 & 384 & 38.4 & 2.56 & $12.16 \pm 0.75$ & $31.7 \pm 3.7$ \\
\hline PHA01C-B & Secondary & Bedrock & 43.7663 & 5.1856 & 384 & 42.6 & 1.37 & $13.36 \pm 0.66$ & $29.2 \pm 3.3$ \\
\hline PHA02C-A & Secondary & Clasts & 43.7650 & 5.1931 & 374 & 41.8 & 4.43 & $13.98 \pm 1.06$ & $27.6 \pm 3.5$ \\
\hline PHA02C-B & Secondary & Bedrock & 43.7650 & 5.1931 & 374 & 39.1 & 4.04 & $12.20 \pm 0.88$ & $31.8 \pm 3.9$ \\
\hline VID03C-A & Secondary & Clasts & 43.8002 & 5.1250 & 548 & 38.3 & 5.48 & $10.93 \pm 0.94$ & $41.7 \pm 5.5$ \\
\hline VID03C-B & Secondary & Bedrock & 43.8002 & 5.1250 & 548 & 40.9 & 7.30 & $11.70 \pm 1.18$ & $39.8 \pm 5.7$ \\
\hline VID04C-A & Secondary & Clasts & 43.8004 & 5.1270 & 561 & 40.7 & 10.44 & $13.77 \pm 1.79$ & $33.5 \pm 5.5$ \\
\hline \multicolumn{10}{|c|}{ Flanks samples } \\
\hline BRO1B-G & South & Gravel & 43.7949 & 5.0952 & 127 & 41.2 & 7.93 & $3.84 \pm 0.67$ & $125.8 \pm 25.3$ \\
\hline ORM01B-G & South & Gravel & 43.7889 & 5.1947 & 342 & 44 & 2.20 & $7.09 \pm 0.49$ & $72.5 \pm 8.8$ \\
\hline ORM02B-G & South & Gravel & 43.7813 & 5.1889 & 274 & 39.8 & 21.70 & $4.07 \pm 1.26$ & $139.2 \pm 45.2$ \\
\hline ORM02B-S & South & Sand & 43.7813 & 5.1889 & 274 & 41.4 & 18.24 & $3.66 \pm 0.94$ & $154.5 \pm 42.7$ \\
\hline ORM03B-G & South & Gravel & 43.7781 & 5.1999 & 265 & 42.7 & 23.23 & $4.22 \pm 1.40$ & $126.9 \pm 43.8$ \\
\hline ORM03B-S & South & Sand & 43.7781 & 5.1999 & 265 & 40.7 & 19.04 & $3.96 \pm 1.14$ & $131.9 \pm 40.1$ \\
\hline PLBS-1G & North & Gravel & 43.8103 & 5.2390 & 343 & 38.1 & 4.22 & $4.53 \pm 0.61$ & $115.1 \pm 19.4$ \\
\hline PLBS-1S & North & Sand & 43.8103 & 5.2390 & 343 & 38.7 & 5.25 & $5.23 \pm 0.78$ & $99.6 \pm 18.0$ \\
\hline PLBS-2S & North & Sand & 43.8151 & 5.2308 & 266 & 37.8 & 4.16 & $4.53 \pm 0.58$ & $111.4 \pm 18.0$ \\
\hline PLBS-3G & North & Gravel & 43.8137 & 5.2024 & 288 & 36.4 & 6.91 & $2.64 \pm 0.50$ & $205.3 \pm 44.2$ \\
\hline PLBS-4G & North & Gravel & 43.8268 & 5.1560 & 191 & 37.7 & 5.85 & $3.11 \pm 0.52$ & $170.4 \pm 33.3$ \\
\hline
\end{tabular}




\begin{tabular}{|c|c|c|c|c|c|c|c|c|c|}
\hline PLS-E1 & South & Sand & 43.7579 & 5.2542 & 187 & 37.9 & 14.35 & $3.77 \pm 1.02$ & $136.4 \pm 39.3$ \\
\hline PLS-E2 & South & Sand & 43.7584 & 5.2341 & 150 & 37.5 & 15.16 & $3.23 \pm 0.90$ & $154.2 \pm 45.4$ \\
\hline REC01B-S & South & Sand & 43.7904 & 5.2898 & 401 & 41.8 & 17.23 & $3.31 \pm 0.92$ & $170.5 \pm 50.4$ \\
\hline REC02B-G & South & Gravel & 43.7899 & 5.3010 & 343 & 38.6 & 19.70 & $3.23 \pm 0.94$ & $179.5 \pm 55.1$ \\
\hline REC02B-S & South & Sand & 43.7899 & 5.3010 & 343 & 41.7 & 22.05 & $3.19 \pm 1.07$ & $186.9 \pm 65.7$ \\
\hline ROQ01B-G & South & Gravel & 43.7741 & 5.1351 & 149 & 40.3 & 8.19 & $4.06 \pm 0.73$ & $118.9 \pm 24.6$ \\
\hline ROQ01B-S & South & Sand & 43.7741 & 5.1351 & 149 & 40.1 & 7.51 & $3.47 \pm 0.60$ & $140.1 \pm 27.9$ \\
\hline TAP01B-G & South & Gravel & 43.7794 & 5.2523 & 282 & 40.6 & 19.43 & $4.88 \pm 1.52$ & $114.0 \pm 37.2$ \\
\hline TAP01B-S & South & Sand & 43.7794 & 5.2523 & 282 & 41.2 & 13.80 & $3.95 \pm 1.08$ & $139.3 \pm 40.7$ \\
\hline TAP02B-G & South & Gravel & 43.7656 & 5.2405 & 182 & 403 & 18.54 & $4.91 \pm 1.51$ & $105.2 \pm 34.0$ \\
\hline TAP02B-S & South & Sand & 43.7656 & 5.2405 & 182 & 40.2 & 17.47 & $4.66 \pm 1.40$ & $110.7 \pm 35.1$ \\
\hline VID01B-S & North & Sand & 43.8160 & 5.1024 & 129 & 40.6 & 6.22 & $4.10 \pm 0.64$ & $125.8 \pm 23.3$ \\
\hline VID02B-S & North & Sand & 43.8152 & 5.1034 & 147 & 40.2 & 7.89 & $3.30 \pm 0.59$ & $159.4 \pm 32.7$ \\
\hline
\end{tabular}

Table 1 - Analytical results for the samples processed in this study.

The samples were crushed, sieved, and chlorine was chemically extracted using AgCl. Natural Chlorine (hereafter $\mathrm{Cl}_{\text {nat }}$ ) and ${ }^{36} \mathrm{Cl}$ concentrations were then determined via isotope dilution accelerator mass spectrometry based on the measured ${ }^{35} \mathrm{Cl} /{ }^{37} \mathrm{Cl}$ and ${ }^{36} \mathrm{Cl} /{ }^{\beta 5} \mathrm{Cl}$ ratio measurements performed at the French national accelerator mass spectrometry (AMS) facility Accélérateur pour les Sciences de la Terre, Environnement, Risques (ASTER) (CEREGE, Aix-en-Provence, France). The ${ }^{36} \mathrm{Cl}$ concentrations were normalized to $a{ }^{36} \mathrm{Cl}$ standard prepared by $\mathrm{K}$. Nishiizumi: KNSTD1600, with a nominal ${ }^{36} \mathrm{Cl}{ }^{35} \mathrm{Cl}$ value of $2.11 \pm 0.06 \times 10^{-12}$ [Sharma et al., 1990; Fifield et al., 1990]. The decay constant of $2.303 \pm 0.016 \times 10^{-6} y r^{-1}$ used corresponds to a ${ }^{36} \mathrm{Cl}$ half-life $\left(T_{1 / 2}\right)$ of $3.014 \times 10^{5}$ years. The analytical uncertainties include counting statistics, machine stability, and blank correction. The measured ${ }^{36} \mathrm{Cl}$ amounts range from $\sim 10^{7}$ to $\sim 6 \times 10^{7}$ atoms, 2 order of magnitude higher than that measured in the blanks $\left(10^{5}\right.$ atoms of $\left.{ }^{36} \mathrm{Cl}\right)$. The measured amount of $C l_{\text {nat }}$ in the samples is 10 times higher than the amount measured in the blanks. $C_{\text {nat }}$ concentrations are on average $10 \mathrm{ppm}$, with one sample reaching up to $47 \mathrm{ppm}$. The different production pathways 
of ${ }^{36} \mathrm{Cl}$ are as follows: spallation of target elements (78\%), slow negative muons capture (19\%) and thermal and epithermal neutron capture (3\%). [Schimmelpfennig et al., 2011]. The ${ }^{36} \mathrm{Cl}$ production rate from spallation of calcium has been calibrated in Sicily by Schimmelpfennig et al. [2011]. Because the Luberon area is located almost at the same latitude and elevation as this calibration site, we used the calibrated production rate of $42.2 \pm 4.8$ atoms $/ g / y r$. Scaling with respect to latitude and elevation was performed considering constant geomagnetic field intensity and using the Stone [2000] scheme. Sand and gravel samples corresponds to the 0.5-2 $\mathrm{mm}$ and 2-30 $\mathrm{mm}$ size ranges, respectively. 
References

Baroux, E., Béthoux, N., Bellier, O., 2001. Analyses of the stress field in southeastern France from earthquake focal mechanisms. Geophysical Journal International, 145, 336-348.

Bestani, L., N. Espurt, J. Lamarche, O. Bellier, and F. Hollender, 2016. Reconstruction of the Provence Chain evolution, southeastern France. Tectonics, 35.

Carretier, S., Regard, V., Vassallo, R., Aguilar, G., Martinod, J., Riquelme, R., Christophoul, F., Charrier, R., Gayer, E., Farías, M., Audin, L., and Lagane, C., 2015. Differences in ${ }^{10} B e$ concentrations between river sand, gravel and pebbles along the western side of the central Andes, Quaternary Geochronology, 27, 33-51.

Champagnac, J.-D., Valla, P. G., Herman, F., 2014. Late-Cenozoic relief evolution under evolving climate: A review. Tectonophysics, 614, 44-65.

Champion, C., P. Choukroune, and G. Clauzon, 2000. La déformation post-Miocène en Provence occidentale, Geodin. Acta, $13,67-85$.

Chardon, C., and O. Bellier, 2003. Geological boundary conditions of the 1909 Lambesc (Provence, France) earthquake: Structure and evolution of the Trevaresse ridge anticline, Bull. Soc. Geol. Fr., 174, 497-510.

Chardon, D., Hermitte, D., Nguyen, F., Bellier, O., 2005. First paleoseismological constraints on the strongest earthquake in France (Provence) in the twentieth century, Geology, 33, 11, 901-904.

Clauzon, G., Fleury, T.J., Bellier, O., Molliex, S., Mocochain, L. and Aguilar, J.P., 2011. Morphostructural evolution of the Luberon since the Miocene (SE France), Bulletin de la Societe Geologique de France, 182, 2, p. 95-110.

Fauquette, S., Bernet, M., Suc, J-P., Grosjean, A-S., Guillot, S., Van der Beek, P., Jourdan, S., Popescu, S-M., Jiménez-Moreno, G., Bertini, A., Pittet, B., Tricart, P., Dumont, T., 
Schwartz, S., Zheng, Z., Roche, E., Pavia, G., Gardien, V., 2015. Quantifying the Eocene to Pleistocene topographic evolution of the southwestern Alps, France and Italy, Earth and Planetary Science Letters, 412, 220-234.

Fifield, L.K., Ophel, T.R., Allan, G.L., Bird, J.R. and Davie, R.F., Nucl. Instr. and Meth. B 52 (1990) 233.

Furlani, S., Cucchi, F., Forti, F., Rossi, A., 2009. Comparison between coastal and inland Karst limestone lowering rates in the northeastern Adriatic Region (Italy and Croatia), Geomorphology, 104, 1, 73-81.

Godard, V., Ollivier, V., Bellier, O., Miramont, C., Shabanian, E., Fleury, J., Benedetti, L., Guillou, V., ASTER T., 2016. Weathering-limited hillslope evolution in carbonate landscapes, Earth Planet. Sci. Lett., 446, 10-20.

Kirby, E., Whipple, K., 2012. Expression of active tectonics in erosional landscapes, Journal of structural geology, 44, 54-75.

Lacombe, O., and L. Jolivet, 2005. Structural and kinematic relationships between Corsica and the Pyrenees-Provence domain at the time of the Pyrenean orogeny, Tectonics, 24, TC1003.

Mandal, S. K., Lupker, M., Burg, J-P., Valla, P. G., Haghipour, N., Christl, M., 2015. Spatial variability of $10 B$-derived erosion rates across the southern Peninsular Indian escarpment: A key to landscape evolution across passive margins, Earth and Planetary Science Letters 425, 154-167.

Matsushi, Y., Sasa, K., Takahashi, T., Sueki, K., Nagashima, Y., Matsukura, Y., 2010. Denudation rates of carbonate pinnacles in Japanese karst areas: estimates from cosmogenic $36 \mathrm{Cl}$ in calcite. Nuclear Instruments and Methods in Physics Research, 268, 1205-1208.

Meyer, H., Hetzel, R., Fügenschuh, B., Strauss, H., 2010. Determining the growth rate of topographic relief using in situ produced 10Be: a case study in the Black Forest, Germany. 
Earth Planet. Sci. Lett. 290, 391-402.

Molliex, S., Bellier, O., Terrier, M., Lamarche, J., Martelet, G., Espurt, N., 2011. Tectonic and sedimentary inheritance on the structural framework of Provence (SE France): Importance of the Salon-Cavaillon fault, Tectonophysics, 501, 1-16.

Nocquet, J.M., 2002. Present-day kinematics of the Mediterranean: A comprehensive overview of GPS results, Tectonophysics, 579, 220-242.

Perron, J.T., Kirchner, J.W., and Dietrich, W.E., 2009, Formation of evenly spaced ridges and valleys: Nature, 460, 7254, 502-505.

Roure, F., Brun, J-P., Colleta, B., Van Den Driessche, J., 1992. Geometry and kinematics of extensional structures in the Alpine Foreland Basin of southeastern France, Journal of Structural Geology, 14, 5, 503-519.

Ryb, U., Matmon, A., Erel, Y., Haviv, I., Benedetti, L. and Hidy, A.J., 2014a. Styles and rates of long-term denudation in carbonate terrains under a Mediterranean to hyper-arid climatic gradient, Earth and Planetary Science Letters, 406, 142-152.

Ryb, U., Matmon, A., Erel, Y., Haviv, I., Katz, A., Starinsky, A., Angert, A. and Team A., 2014b. Controls on denudation rates in tectonically stable Mediterranean carbonate terrain, Geological Society of America Bulletin, 126, 3-4, 553-568.

Ryb, U., Matmon, A., Haviv, I., and Benedetti, L., 2015. Exhumation and uplift coupled with precipitation along the western Dead Sea Rift margin, Geology, 43, 6, 483-486.

Schimmelpfennig, I., Benedetti, L., Finkel, R., Pik, R., Blard, P.-H., Bourlès, D., Burnard, P., Williams, A., 2009. Sources of in-situ $36 \mathrm{Cl}$ in basaltic rocks. Implications for calibration of production rates, Quaternary Geochronology, 4, 6, 441-461.

Schimmelpfennig, I., Benedetti, L., Garreta, V., Pik, R., Blard, P-H., Burnard, P., Bourlès, D., Finkel, R., Ammon, K. and Dunai, T., 2011. Calibration of cosmogenic 36Cl production rates from $\mathrm{Ca}$ and $\mathrm{K}$ spallation in lava flows from $\mathrm{Mt}$. Etna $\left(38^{\circ} \mathrm{N}\right.$, Italy) and Payun Matru (36 ${ }^{\circ}$, Argentina), Geochimica et Cosmochimica Acta, 75, 10, 2611-2632. 
Schlagenhauf, A., Gaudemer, Y., Benedetti, L., Manighetti, I., Palumbo, L., Schimmelpfennig, I., Finkel, R., Pou, K., 2010. Using in situ Chlorine-36 cosmonuclide to recover past earthquake histories on limestone normal fault scarps: a reappraisal of methodology and interpretations, Geophys. J. Int., 182, 36-72.

Sharma, P., Kubik, P.W., Fehn, U., Gove, H.E., Nishiizumi, K., Elmore, D., 1990. Nucl. Instr. Meth., B 52, 410.

Siame, L., Bellier, O., Braucher, R., Sébrier, M., Cushing, M., Bourlès, D., Hamelin, B., Baroux, E., De Voogde, B., Raisbeck, G., Yiou, F., 2004. Local erosion rates versus active tectonics: cosmic ray exposure modelling in Provence (south-east France), Earth Planet. Sci. Lett., 220(3-4), 345-364.

Stone, J., Allan, G.L., Fifield, L.K., Evans, J.M., Chivas, A.R., 1994. Limestone erosion measurements with cosmogenic chlorine-36 in calcite - preliminary results from Australia, Nuclear Instruments and Methods in Physics Research, B 92, 311-316.

Stone, J.O., 2000. Air pressure and cosmogenic isotope production, J. Geophys., 105, 2375323759.

Xu, S., Liu, C., Freeman, S., Lang, Y., Schnabel, C., Tu, C., Wilcken, K., Zhao, Z., 2013. Insitu cosmogenic ${ }^{36} \mathrm{Cl}$ denudation rates of carbonates in Guizhou karst area, Chinese Science Bulletin, 58, 2473-2479. 